\title{
MANHAJ PENETAPAN FATWA HUKUM EKONOMI SYARIAH DI INDONESIA
}

\author{
Rahman Helmi \\ Mahasiswa Program S.3 Prodi Ilmu Syariah UIN Antasari Banjarmasin. \\ e-Mail:muraaf@gmail.com
}

\begin{abstract}
Nowadays, legal issues related to sharia economy are continuing to increase along with the development of banking industry and Islamic finance. Yet, the number of authoritative quotation is very limited, and it has even stopped. In such situation, the muftis must make an ijtihad and give a fatwa regarding to sharia economic law. Fatwa from the National Sharia Board-Council of Indonesian Ulama (MUI DSN) has become unseparable part in the development of sharia banking industry in Indonesia. Many DSN-MUI's fatwas are based on Islamic law solutions. At least, there are four fiqh solutions used as the basis for establishing the fatwas. They are al-taysir al-manhaji, tafriq al-halal 'an al-haram, i'a al nazar, and tahqi al-mana.
\end{abstract}

Keywords: ijtihad, manhaj, DSN's fatwa, Islamic Law Solutions

\begin{abstract}
Abstrak: Persoalan-persoalan hukum yang muncul terkait ekonomi syariah itu terus bertambah seiring dengan perkembangan industri perbankan dan keuangan syariah belakangan ini. Sementara itu, jumlah nas sangat terbatas bahkan sudah terhenti. Dalam situasi seperti itu, maka para ulama harus melakukan ijtihād dan memberikan fatwa mengenai hukum ekonomi syariah. Fatwa Dewan Syariah Nasional Majelis Ulama Indonesia (DSN MUI) telah menjadi bagian tak terpisahkan dalam perkembangan industri keuangan syariah di Indonesia. Fatwa-fatwa DSN-MUI banyak yang mempergunakan solusi hukum Islam sebagai landasannya. Setidaknya ada empat solusi fikih yang dijadikan landasan dalam menetapkan fatwa DSN MUI, yaitu al-taysìr al-manhaji, tafríq al-ḥalāl 'an al-ḥaräm, i'ādah alnazar, dan tahqqiq al-manăt.
\end{abstract}

Kata kunci: ijtihād, manhaj, fatwa DSN, solusi hukum Islam,

\section{Latarbelakang}

Ada sebagian orang berpikir bahwa sistem ekonomi syariah akan melahirkan stagnasi (jumud) dan sekaligus membawa kepada pandangan

${ }^{1}$ Wael B. Hallaq, Ancaman Paradigma Negara-Negara (Islam, Politik, dan Problem Moral Modern), trans. Akh. Minhaji (2013). bahwa berbagai ketentuan hukum Islam tidak bisa diubah (immutable). ${ }^{1}$ Pemikiran demikian muncul hanya karena ketidaktahuan sumber acuan Islam dan karakteristiknya. Dalam 
Islam, yang tidak mungkin berubah hanyalah kaidah-kaidah dasar syariah dan berbagai pondasi dasar. Dalam hal yang bersifat kondisional, misalnya menyangkut hal teknis, Islam memang tetap mengacu dan merujuk sumber asalnya sekaligus melibatkan peran akal. Peran ini yang kemudian disebut dalam terminologi fikih sebagai ijtihād. $^{2}$

Pilihan menjadikan sistem ekonomi syariah sebagai pengganti sistem ekonomi yang sudah ada tidaklah mudah. Pada mulanya pihakpihak yang meyakini dan memperjuangkan sistem ekonomi syariah sebagai sistem ekonomi alternatif yang berkeadilan dianggap sebeah mata. Keyakinan bahwa sistem ekonomi syariah dapat menutupi kelemahan dan kekurangan sistem ekonomi kapitalis atau sosialis dianggap sebagai keyakinan yang berlebihan dan bahkan dianggap sebagai sebuah pernyataan bombastisidealistis. Kondisi seperti ini memang merupakan fakta sejarah yang terjadi di negara-negara Islam, tidak terkecuali di Indonesia. Sampai dengan awal tahun

${ }^{2}$ M. Faruq an-Nabhan, Sistem Ekonomi Islam: Pilihan Setelah Kegagalan Sistem Kapitalis dan Sosialis (Yogyakarta: UII Press, 2000), h. 19.

3 Riba, yaitu penambahan pendapatan secara tidak sah (batil), antara lain dalam transaksi pertukaran barang sejenis yang tidak sama kualitas, kuantitas, dan waktu penyerahan (fadhl), atau dalam transaksi pinjam meminjam yang mensyaratkan nasabah penerima fasilitas mengembalikan dana yang diterima melebihi pokok pinjaman karena berjalannya waktu (nasi'ah). Maisir, yakni transaksi yang 1990-an, pandangan sinis terhadap pihak-pihak yang gigih memperjuangkan sistem ekonomi syariah masih nyaring terdengar. Namun seiring berjalannya waktu, perjuangan untuk pengakuan sistem ekonomi syariah sebagai sistem ekonomi alternatif mulai diterima.

Sistem ekonomi syariah melahirkan sub-sub sistem, seperti sistem keuangan syariah. Sistem keuangan syariah bukan sekedar transaksi komersial, tetapi harus sudah sampai kepada lembaga keuangan untuk dapat mengimbangi tuntutan zaman. Bentuk sistem keuangan atau lembaga keuangan yang sesuai dengan prinsip syariah adalah terbebas dari unsur-unsur riba, maysir, gharar, haram dan zalim ${ }^{3}$.

Perkembangan industri perbankan dan keuangan syariah belakangan ini mengalami kemajuan yang pesat, seperti: perbankan syariah, asuransi syariah, pegadaian syariah, pasar modal syariah dengan instrumennya saham syariah, obligasi syariah (sukuk), dan reksa dana syariah, dan baitul mal wat-tamwil (BMT).

digantungkan kepada suatu keadaan yang tidak pasti dan bersifat untung-untungan. Gharar, yakni transaksi yang objeknya tidak jelas, tidak dimiliki, tidak diketahui keberadaannya, atau tidak diserahkan pada saat transaksi dilakukan, kecuali diatur lain dalam syariah. Haram, yaitu transaksi yang objeknya dilarang dalam syariah. Zalim, yakni transaksi yang menimbulkan ketidakadilan bagi pihak lainnya. (Lihat penjelasan Pasal 2 UU No. 21 Tahun 2008 tentang Perbankan Syariah) 
Demikian pula di sektor riil, seperti: hotel syariah, multilevel marketing syariah, rumah sakit syariah, dsb. Hal yang harus disikapi dengan cermat dan teliti agar perkembangan ini tidak berakhir dengan stagnan, tentunya pengembangan kualitas sumber daya insani yang merupakan salah satu indikator penting dalam pertumbuhan ekonomi syariah.

Bahwa persoalan-persoalan hukum yang muncul terkait ekonomi syariah itu terus bertambah dan tidak terbatas jumlahnya, sedangkan jumlah nas itu terbatas dan sudah berhenti, tidak turun lagi. Dalam situasi seperti itu, maka para ulama wajib membantu kaum muslimin melalui ijtihäd dan pemberian fatwa mengenai hukum masalah-masalah baru tersebut. Membiarkan masyarakat untuk menjawab sendiri persoalan hukum mereka, amatlah berbahaya. ${ }^{4}$

Dalam perspektif hukum Islam, terdapat dua esensi hukum, yaitu syariah dan fikih. Syariah merupakan aturan hukum yang ditetapkan langsung oleh al-Qur'an dan Sunnah.

4 Ma'ruf Amin, Fatwa dalam Sistem Hukum Islam (Jakarta: Elsas, 2008), h. 241.

5 Disfa Lidian Handayani, "Hukum Ekonomi Syari'ah: Tantangan dan Peluang dalam Pengembangan Inovasi Instrumen Keuangan Syariah," Al-Manahij: Jurnal Kajian Hukum Islam Vol. 9. No. 2(Desember 2015): h. 335.

${ }^{6}$ Ibnu Qayyim al-Jauziyyah (691-751H) adalah seorang Imam Sunni, cendikiawan, dan ahli fikih yang hidup pada abad ke-13. Ia adalah ahli fikih madzhab Hanbali, disamping itu juga beliau ahli tafsir, ahli hadits, menghafal al-
Sedangkan fikih adalah aturan hukum yang secara keseluruhan merupakan hasil dari ijtihad ulama. ${ }^{5}$ Ijtihàd sangat diperlukan pada saat ini sebagai jawaban dari berbagai permasalahan yang belum ada pada masa lalu. Ijtihād diperlukan pula dalam pengembangan hukum ekonomi syariah.

Dalam kaidah fiqhiyyah, bahwa perubahan hukum dalam fikih dapat dibenarkan, bahkan bisa menjadi suatu keharusan jika kondisi sosiologis masyarakat berubah. Sebuah kaidah tentang perubahan hukum yang dinisbatkan kepada Ibnu Qayyim alJauziyyah ${ }^{6}$ berbunyi:

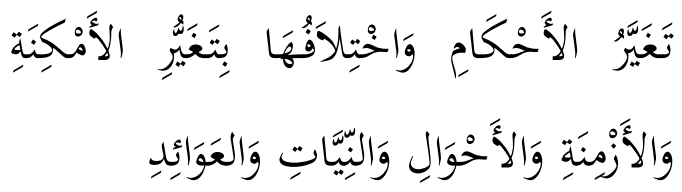

"Perubahan dan perbedaan hukum adalah disebabkan perbedaan tempat, masa, kondisi, motivasi dan budaya".

Kaidah tersebut tidak hanya dikemukakan oleh Ibnu Qayyim, ${ }^{7}$ namun juga oleh ulama yang lain seperti kaidah yang berbunyi:

Qur'an, ahli ilmu Nahwu, ahli Usul, ahli ilmu Kalam, sekaligus seorang Mujtahid. Murid Syaikh al-Islam Ibnu Taimiyyah dalam bidang Ilmu Fikih. Beberapa karya besarnya antara lain; Tahdzib Sunan Abi Dawud, I'lam alMuwaqqi'in an Rabbil 'Alamin, Ighatsatul Lahfan fi Hukmi Thalaqi al-Ghadlban, Ighatsatul Lahfan fi Masha'id al-syaithan, Bada'i'ul Fawa'id, Amtsalul Qur'an dan Buthlanul Kimiya' min Arba'ina Wajhan.

${ }^{7}$ Muhammad Ibnu Qayyim alJauziyyah, I'lam al-Muwaqqi'in 'an Rabb al'Alamin (Beirut: Dar al-Jail, t.t.), h. 3. 


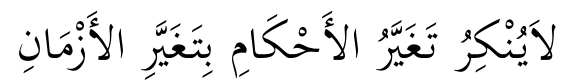

"Tidak diingkari perubahan hukum disebabkan perubahan masa”.

Tulisan ini bertujuan

menganalisis perkembangan berbagai ijtihād dalam bidang ekonomi syariah di Indonesia saat ini. Bagaimana manhaj penetapan fatwa tentang ekonomi syariah di Indonesia. Penetapan fatwa-fatwa tentang kebolehan atau keharaman instrumen keuangan yang merupakan ijtihad yang menjadi acuan dasar dalam pembuatan hukum positif di Indonesia.

\section{Perkembangan Lembaga Keuangan Syariah di Indonesia}

Bank syariah pertama didirikan tahun 1991 merupakan tindak lanjut dari hasil lokakarya MUI pada tahun sebelumnya. Satu tahun setelah berdirinya bank syariah pertama tersebut lahir Undang-Undang Nomor 7 Tahun 1992 tentang Perbankan, yang memuat aturan tentang telah dimungkinkannya kegiatan usaha perbankan dengan menggunakan prinsip syariah yang disebut dengan istilah bagi hasil.

Pada tahun yang sama, Pemerintah menerbitkan Peraturan Pemerintah Nomor 72 Tahun 1992 tentang Bank Berdasarkan Prinsip Bagi Hasil. Dalam PP Nomor 72 Tahun 1992 pasal 1 tersebut, ditetapkan bahwa bank berdasarkan prinsip bagi hasil wajib memiliki Dewan Pengawas Syariah, (ayat 1) yang dibentuk atas dasar konsultasi dengan ulama (ayat 2), dan ulama yang dimaksud adalah MUI (penjelasan pasal 5 ayat 2).

Selanjutya, pemerintah menerbitkant UU No. 10 Tahun 1998 Tentang Perubahan atas Undangundang No. 7 Tahun 1992 tentang Perbankan, yang secara jelas di dalamnya mengakomodasi dual banking system di Indonesia, yaitu perbankan konvensional dan perbankan syariah.

Terakhir pada tahun 2008 terbit UU No. 21 Tahun 2008 Tentang Perbankan Syariah yang memiliki nuansa mensyariahkan bank syariah, hal tersebut terlihat dari ketentuan tentang jenis dan kegiatan usaha, pelaksanaan prinsip syariah, komite perbankan syariah dan komisaris syariah, serta dewan pengawas syariah.

Hubungan baik yang terjalin antara Bank Indonesia dan Dewan Syariah Nasional-Majelis Ulama Indonesia (DSN-MUI) telah menghasilkan banyak Peraturan Bank Indonesia (PBI) yang mengadopsi dan mengharmonisasi fatwa-fatwa DSNMUI. Sehingga dapat dikatakan bahwa penyerapan fatwa ke dalam peraturan resmi negara telah berlangsung dengan baik di sektor perbankan. Hal yang sama juga terjadi di sektor lain; seperti sektor asuransi, pembiayaan, dan pasar modal.

Pada tahun 2003, MUI merilis fatwa tentang keharaman bunga bank, karena dinilai sama dengan riba. Efek berantai setelah dikeluarkannya fatwa tersebut segera terasakan setelahnya. Hal ini bisa dilihat dari ditetapkannya 
bagian khusus di lembaga regulator yang menangani masalah ekonomi syariah, baik di Bank Indonesia melalui Direktorat Perbankan Syariah yang khusus menangani perbankan syariah, maupun di Departemen Keuangan melalui Direktorat Pembiayaan Syariah, Bapepam-LK, Biro Asuransi Syariah, Bursa Efek Indonesia (BEI), yang kesemuanya saat ini disatuatapkan di dalam Otoritas Jasa Keuangan (OJK).

Fatwa tersebut juga mempunyai pengaruh kuat terhadap semakin berkembangnya industri keuangan dan bisnis syariah. Hal itu bisa dibuktikan melalui fakta statistik yang ada. Pada rentang tahun 1990 sampai dengan 1998 hanya ada satu bank syariah. Pada rentang tahun 1998 sampai dengan tahun 2002 lahir lima bank syariah. Sedangkan setelah fatwa keharaman bunga bank dikeluarkan pada tahun 2003, semakin banyak muncul bank syariah, baik yang berupa Unit Usaha Syariah ataupun Bank Umum Syariah. Hal yang serupa juga terjadi di sektor non-bank; banyak lahir asuransi syariah, multi-finance syariah, pasar

8 K.H. Ma'ruf Amin adalah seorang ulama besar yang dimiliki bangsa ini. Beliau dilahirkan di Tangerang Banten, pada tanggal 11 Maret 1943. Beliau memulai pendidikannya di Sekolah Rakyat sekaligus Madrasah Ibtidaiyyah di Tangerang yang diselesaikan pada tahun 1955. Kemudian, beliau meneruskan pendidikannya di Pesantren Tebuireng Jombang Jawa Timur sampai 1961. Pendidikan formal beliau terakhir adalah Fakultas Ushuluddin Universitas Ibnu Chaldun Bogor yang dituntaskannya pada tahun 1967. Sebagai modal syariah, dan lembaga bisnis syariah lainnya. Hal itu semakin dikukuhkan dengan lahirnya UU Nomor 19 Tahun 2008 tentang Surat Berharga Syariah Negara (SBSN) dan UU Nomor 21 Tahun 2008 tentang Perbankan Syariah.

Hal ini semakin menunjukkan ada hubungan yang kuat sekali antara fatwa yang dikeluarkan oleh DSN-MUI dengan terbentuknya peraturan perundang-undangan dan dinamika tumbuh kembang sektor ekonomi syariah di Indonesia.

\section{Manhaj Penetapan Fatwa Dewan Syariah Nasional}

Menurut KH. Ma'ruf Amin', Ketua Umum Majelis Ulama Indonesia (2015-2020), salah satu syarat untuk berijtihad atau menetapkan fatwa adalah harus memenuhi metodologi atau manhaj. Menetapkan fatwa tanpa manhaj, dilarang oleh agama. Kelompok yang menetapkan fatwa hanya didasarkan kepada kebutuhan (li al-hajah), atau kemaslahatan (li almaslahah), atau pemahaman tentang intisari ajaran agama (maqāșid al-

salah satu penghargaan atas peran dan karya besarnya bagi bangsa dan negara. K.H. Ma'ruf Amin memperoleh gelar Doktor Kehormatan dalam bidang Ilmu Hukum Ekonomi Syariah dari UIN Syarif Hidayatullah, Jakarta pada tanggal 5 Mei 2012. K.H. Ma'ruf Amin ini termasuk salah satu cicit dari ulama besar, Syaikh Nawawi al-Bantani. Beberapa karier beliau adalah Ra'is 'Aam PBNU (2015-2020) dan Ketua Umum Majelis Ulama Indonesia (2015-2020). Lihat https://id.wikipedia.org/wiki/Maruf_Amin 
syari'ah), tanpa berpegang kepada alnușūs al-syar'iyyah, termasuk kelompok yang kebablasan (ifräti). Sebaliknya kelompok yang rigid memegangi teks keagamaan (al-nusūus al-syari'iyyah) tanpa memperhatikan kemaslahatan (al-maslahah) dan intisari ajaran agama (maqāșid al-syari'ah), sehingga banyak permasalahan baru yang tidak dijawab, termasuk kategori bersikap gegabah (tafriti $i) .{ }^{9}$

Manhaj Fatwa Dewan Syariah Nasional (DSN) secara prosedural ialah terlebih dahulu mencari jawaban atas masalah yang dihadapi dengan mengeceknya dalam al-Qur'an dan Sunnah. Jika jawaban itu ternyata ada di sana, maka persoalan itu terjawab sudah dan selesai. Jika tidak ada, barulah mencari kalau-kalau sudah ada ijmä' ulama tentang hal itu. Kemudian jika tidak ada juga dalam ijmā', barulah mencari jawabannya dengan melakukan qiyās. Prosedur empat langkah ini telah disepakati para ulama. ${ }^{10}$ Jika terjadi kebuntuan pada langkah keempat (qiyas), maka KH. Ma'ruf Amin mengusulkan ditempuhnya langkah Solusi Hukum Islam (makharij fiqhiyah) sebagai landasannya. Setidaknya ada 4 (empat) solusi fikih yang dijadikan landasan dalam menetapkan fatwa DSN-MUI, yaitu: altaysìr al-manhaji, tafríq al-ḥalāl 'an al-

9 Amin, Fatwa dalam Sistem Hukum Islam, h. 246.

${ }^{10}$ Ibid., h. 253.

11 Ma'ruf Amin, "Solusi Hukum Islam (Makharij Fiqhiyyah) Sebagai Pendorong Arus Baru Ekonomi Syariah di Indonesia (Kontribusi harām, i'ādah al-nazar, dan tahqqīq almanăt. ${ }^{11}$

\section{a. Al-taysir al-manhaji}

Al-taysir al-manhaji dapat diartikan memilih pendapat yang ringan namun tetap sesuai aturan. Meskipun mengambil pendapat yang lebih meringankan namun tetap dalam koridor manhaj yang ada. Artinya, fatwa DSN-MUI akan memberikan jalan keluar dengan memberikan solusi terbaik selama tidak bertentangan dengan syariah. Namun demikian, penggunaan metode tersebut tidak boleh dilakukan secara berlebihan. Hal itu tidak dibenarkan karena menimbulkan sikap meremehkan.

Metode al-taysir al-manhaji dimaksudkan agar menghindarkan fatwa disahkan tanpa mengikuti pedoman. Tidak jarang suatu masalah dijawab dengan fatwa yang meringankan namun hanya mempertimbangkan aspek kemaslahatan saja dan tidak mengindahkan aspek kesesuaian metodologis. Dalam pandangan KH. Ma'ruf Amin, hal itu tidak boleh dilakukan karena berpotensi terperosok pada mencari-cari hal-hal yang ringan saja yang dilarang dalam syariah Islamiyah.

Prinsip dasar penerapan metode al-taysir al-manhaji dalam fatwa DSN-

Fatwa DSN-MUI dalam Peraturan Perundangundangan RI)," in Orasi Ilmiah Pengukuhan Guru Besar Bidang Ilmu Ekonomi Muamalat Syariah (Malang: UIN Maulana Malik Ibrahim, 24 Mei 2017), h. 7. 
MUI adalah "menggunakan pendapat yang lebih räjih dan lebih maslahat jika memungkinkan; jika tidak, maka yang digunakan adalah pendapat yang lebih maslahat (saja)". ${ }^{12}$

Langkah operasionalnya adalah mencari solusi fikih yang secara dalil lebih kuat dan sekaligus lebih membawa kemaslahatan. Namun apabila hal itu tidak bisa (atau sulit) dilakukan, maka yang didahulukan adalah pertimbangan kemaslahatan, sedangkan kekuatan dalil dijadikan pertimbangan setelahnya. Karena itu, tidak menutup kemungkinan dalam fatwa DSN-MUI didasarkan pada pendapat ulama yang dulu dianggap sebagai pendapat lemah, namun karena situasi dan kondisi saat ini pendapat tersebut dianggap lebih membawa kemaslahatan. Contohnya adalah penerapan kaidah penetapan hukum ekonomi syariah yang selama ini dikenal ada dua pandangan, yakni pandangan substantif yang menjadikan tujuan/hasil akhir dan isi (al-maqāsid wa al-ma'āni) sebagai ugeran dalam menentukan hukum; dan pandangan legal-formal yang menggunakan kata/ kalimat dan bentuk (al-alfāz wa almabāni) sebagai ugeran dalam menentukan hukum. Yang pertama menggunakan kaidah:

\footnotetext{
${ }^{12}$ Ibid., h. 8 .

13 Rozalinda, Fikih Ekonomi Syariah Prinsip dan Implementasinya pada Sektor Keuangan Syariah (Jakarta: Rajawali Press,
}

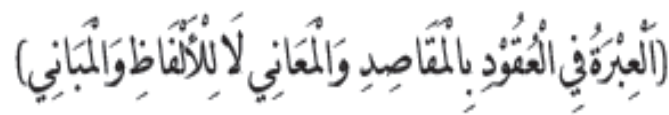

"Yang dianggap (penting) dalam akad adalah maksud dan makna bukan lafal dan bentuk perkataannya".13

Sedangkan yang kedua menggunakan kaidah:

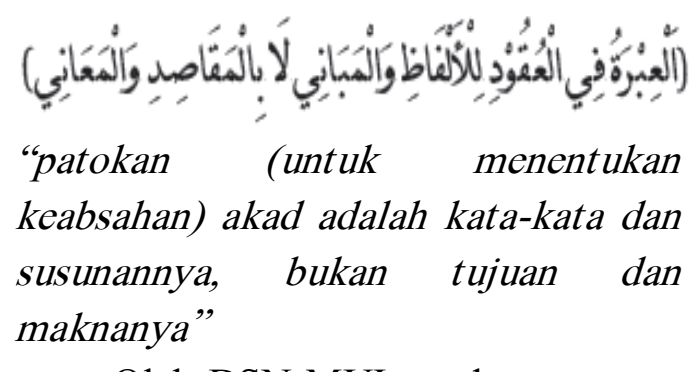

Oleh DSN-MUI pandangan yang terlihat antagonis tersebut dua-duanya diadopsi dan dipakai dalam menetapkan fatwa DSN- MUI, tergantung mana yang paling punya relevansi dengan aspek kemaslahatan. Contoh untuk pengadopsian pandangan pertama adalah fatwa tentang akad wadi'ah (digunakan untuk kegiatan penghimpunan dana berupa tabungan dan giro); akad wadi'ah adalah bentuk formalnya (al-alfäz wa al-mabāni) sedangkan substansinya (al-maqāṣid wa al-ma'āni) merupakan akad qarḍ, karena akad wadi'ah yang terdapat izin dari pemilik untuk menggunakan barang titipan oleh penerima titipan, dan barang titipan dapat diganti oleh barang lain (yang senilai/serupa) sejatinya merupakan akad qard.

2016), h. 400. Lihat 'Ali Ahmad al-Nazwi, alQawa'id al-Fiqhiyyah (Damsyiq: Dar al Qalam, 2000), h. 64. 
Sedangkan contoh penerapan pandangan kedua dalam fatwa DSNMUI adalah fatwa terkait mengikatnya (mulzim) saling berjanji (almuwăàadah) dan hubungannya dengan mulzim-nya perjanjian (al-'aqd) sebagaimana dalam fatwa DSN-MUI Nomor 28/DSN-MUI/ III/2002 tentang Jual-Beli Uang (al-Sarf), fatwa DSNMUI Nomor: 85/DSN-MUI/XII/2012 tentang Janji ( $\mathrm{Wa}^{\prime} \mathrm{ad}$ ) dalam Transaksi Keuangan dan Bisnis Syariah, dan fatwa DSN-MUI Nomor 96/DSNMUI/IV/2015 tentang Transaksi Lindung Nilai Syariah (al-Tahāwwut al-Islami/Islamic Hedging). Fatwa tersebut menyatakan bahwa lindung nilai secara syariah boleh dilakukan dengan syarat dilakukan atas dasar kebutuhan nyata (tidak untuk untungunt ungan/spekulasi/garar) dan dilakukan melalui mekanisme forward agreement (saling berjanji) untuk melakukan pertukaran mata uang di masa yang akan datang.

Akad dan muwąa'adah (saling berjanji) dari sisi bentuknya memiliki kesamaan, yaitu pihak yang melakukannya sama (dilakukan oleh dua pihak atau lebih), dan dari sisi sifatnya juga memiliki kesamaan, yaitu mengikat (mulzim) untuk dilakukan. Akan tetapi perbedaan antara keduanya bersifat mendasar; yaitu dalam muwā'adah belum muncul hak dan kewajiban, sedangkan dalam akad sudah muncul. Oleh karena itu, disebut bahwa saling berjanji mirip dengan akad (al-muwā'adatu tusybih al-'aqd). Namun sejatinya kedua hal tersebut berbeda, saling berjanji bukanlah akad (wa laisa al-muwā'adatu 'aqdan). Apabila saling berjanji dianggap sama hukumnya dengan akad, maka transaksi lindung nilai terlarang karena termasuk jual-beli utang dengan utang (bay'u aldain bi al-dain). Namun kalau saling berjanji dihukumi bukan akad (sebagaimana disebutkan dalam fatwa DSN-MUI), maka transaksi tersebut dibolehkan, karena terhindar dari jualbeli utang dengan utang.

\section{b. Tafrīq al-halāl 'an al-harām}

Metode berikutnya adalah terkait dengan pemisahan antara harta halal dan non-halal (at-tafríq bain al-ḥalāl 'an al-ḥarām). Umumnya, orang memahami bahwa percampuran antara yang halal dan yang haram, maka dimenangkan yang haram, sesuai kaidah berikut:

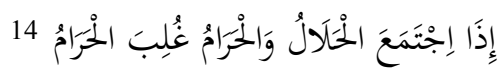

"Apabila bercampur antara yang halal dan yang haram, maka percampuran tersebut dihukumi haram".

DSN-MUI memandang kaidah tersebut tidak tepat diterapkan dalam bidang ekonomi. Kaidah tersebut lebih tepat digunakan dalam bidang pangan, khususnya benda atau barang yang cair. Halal-haram dalam bidang pangan terkait dengan bahannya ('ain), sehingga jika terjadi percampuran maka akan terjadi persinggungan dan

\footnotetext{
${ }^{14}$ al-Nazwi, al-Qawa'id al-Fiqhiyyah, h.
} 171. 
persenyawaan yang sulit dipisahkan. Dalam kondisi seperti itu maka tepat menggunakan kaidah "apabila bercampur antara yang halal dan yang haram, maka percampuran tersebut dihukumi haram".

Namun berbeda halnya apabila pemisahan antara yang halal dari yang haram dapat dilakukan, misalnya dalam kasus percampuran antara harta yang halal dan yang tidak halal, maka kaidah tersebut tidak cocok diterapkan, dan yang lebih tepat adalah menggunakan kaidah pemisahan yang halal dari yang haram (tafríq bain al-ḥalāl 'an alharām). Maksudnya bahwa harta atau uang dalam perspektif fikih bukanlah benda haram karena zatnya ('ain) tapi haram karena cara memperolehnya yang tidak sesuai syariah (li gairih), sehingga dapat untuk dipisahkan mana yang diperoleh dengan cara halal dan mana yang non halal. Dana yang halal dapat diakui sebagai penghasilan sah, sedangkan dana non-halal harus dipisahkan dan dialokasikan untuk kepentingan umum. ${ }^{15}$

Dasar kaidah ini dapat dirujuk pada as-Suyūṭi dalam kitab Al-Asybāh wa al-Nazā'ir.

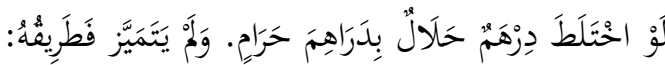

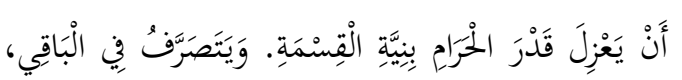

\footnotetext{
${ }^{15}$ Ma'ruf Amin, Era Baru Ekonomi Islam Indoneia: Dari FIkih ke Praktek Ekonomi Islam (Jakarta: Elsas, 2011), h. 48-52.

16 'Abdurrahman bin Abi Bakr Jalaluddin al-Suyuti, al-Asybah wa al-Naza'ir (Dar alKutub al-Amaliah 1990/1411), h. 107.
}

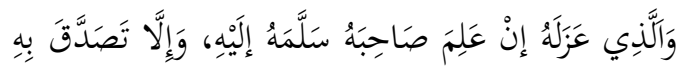
16 عَنْ

Jika uang yang halal tercampur dengan uang yang haram dan tidak dapat dibedakan, maka jalan keluarnya adalah memisahkan bagian yang haram serta menggunakan sisanya. Sedangkan bagian haram yang dikeluarkan, jika ia tahu pemiliknya maka ia harus menyerahkannya atau bila tidak maka harus disedekahkan.

Senada dengan hal tersebut Ibnu Taimiyyah dalam kitab Fatāwā alKubrā li Ibn Taimiyyah menyatakan:

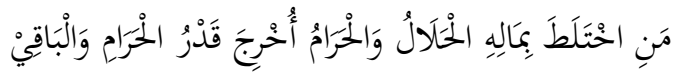

$$
\begin{aligned}
& 17 \text { حَلَّلٌ لَالَ }
\end{aligned}
$$

Jika seorang hartanya tercampur antara unsur yang halal dan yang haram maka unsur haram harus dikeluarkan nominalnya, dan sisanya halal baginya. Pertimbangan penggunaan metode tafríq al-halāl 'an al-ḥaram pada fatwa DSN-MUI adalah bahwa dalam konteks Indonesia kegiatan ekonomi syariah belum bisa dilepaskan sepenuhnya dari sistem ekonomi konvensional yang ribawi. Institusi ekonomi syariah masih berhubungan dengan institusi ekonomi konvensional yang ribawi dari aspek permodalan, pengembangan produk, maupun

\footnotetext{
${ }^{17}$ Ibn Taimiyah, "Al-Fatawa al-Kubra li
} Ibn Taimiyah," (Dar al-Kutub al-Alamiyah, 1987/1408), h. 74. Lihat pula 'Ali Ahmad alNadawi, Mausu'ah al-Qawa'id wa al-Dawabit al-Fiqhiyyah fi al-Fiqh al-Islami, Jilid I (Riyad: Markaz al-Buhus Dar al-Ta'sil, 1999), h. 344. 
keuntungan yang diperoleh. Pendirian bank syariah atau unit usaha syariah (UUS) oleh bank konvensional adalah contoh yang nyata terjadi. Metode ini merupakan jawaban atas komentar banyak pihak tentang berdirinya bankbank syariah, terutama UUS yang dibentuk atau didirikan oleh bank-bank konvensional. Di antara umat Islam, ada yang meragukan kehalalan produk unit usaha syariah karena modal pembentukan berasal dari bank konvensional yang termasuk perusahaan ribawi. Metode ini diaplikasikan dengan cara mengidentifikasi seluruh uang yang menjadi milik bank konvensional sehingga diketahui mana yang merupakan bunga dan mana yang merupakan modal atau pendapatan yang diperoleh dari jasa-jasa yang tidak didasarkan pada bunga. Pendapatan bank yang berasal dari bunga disisihkan terlebih dahulu, maka sisanya dapat atau boleh dijadikan modal pendirian bank syariah atau UUS karena diyakini halal.

\section{c. I'àdah al-nazar}

Metode berikutnya dalam upaya penerapan solusi fikih adalah $i$ 'àdah alnazar (telaah ulang). Telaah ulang terhadap pendapat ulama terdahulu bisa dilakukan dalam hal pendapat ulama terdahulu dianggap tidak cocok lagi untuk dipedomani karena faktor sulit diimplementasikan. ${ }^{18}$ Telaah ulang salah satu caranya dilakukan dengan

18 Amin, Fatwa dalam Sistem Hukum Islam, h. 261-62. . menguji kembali pendapat yang mu'tamad dengan mempertimbangkan pendapat hukum yang selama ini dipandang lemah (marjūh bahkan mahjür), karena adanya 'illat hukum yang baru dan/atau pendapat tersebut lebih membawa kemaslahatan; kemudian pendapat tersebut dijadikan pedoman (mu'tamad) dalam menetapkan hukum.

Metode ini merupakan jalan tengah atau moderat di antara pemikiran pakar hukum ekonomi syariah yang terlalu longgar (mutasahhil) dalam menerapkan prinsip-prinsip hukum ekonomi syariah, sehingga ekonomi Islam terjebak pada labeling. Sebaliknya dengan teori ini pengembangan ekonomi Islam tidak terlalu ketat dan terikat dalam kaidahkaidah dan pemikiran fiqh klasik yang mungkin sulit diaplikasikan kembali pada era sekarang (mutasyaddid). Dasar metode ini adalah kaidah:

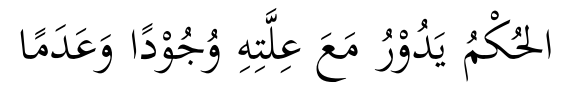

"Hukum itu beredar pada 'illat-nya, baik adanya hukum maupun tidak adanya".

Secara operasional, acuan perubahan hukum menurut kaidah usul fikih di atas adalah menurut ada atau tidak adanya 'illat hukumnya. 'Illat adalah suatu sifat pada suatu hal yang hukumnya ditetapkan oleh nas (al-aṣlu) yang atasnya ditegakkan hukum. Jika 
ada 'illat maka disitu ada hukum, dan sebaliknya, jika tidak adanya 'illat maka tidak ada hukum.

Contoh penerapannya adalah fatwa terkait posisi wakil dalam akad sewa-menyewa; wakil boleh menyewa benda yang dipercayakan kepadanya untuk disewakan. Pendapat ini dijadikan pegangan oleh DSN-MUI meskipun bertentangan dengan pendapat mayoritas ulama setelah melakukan telaah ulang ( $i$ 'ādah alnazar) terhadap 'illah hukum yang dikemukan Jumhur ulama. Jumhur ulama berpendapat bahwa larangan bagi wakil menyewa benda yang diserahkan kepadanya untuk disewakan kepada orang lain karena adanya tuhmah (diduga kuat ada kebohongan) dari wakil sehingga dapat merugikan pemilik. Namun bila dilakukan telaah ulang terhadap 'illah hukum tersebut, maka 'illah hukum tersebut akan hilang bila pemilik memberikan tarif yang jelas terhadap benda yang akan disewakan kepada wakilnya, lalu wakil menyepakati tarif tersebut dan kemudian ia menyewa sendiri harta benda tersebut. ${ }^{19}$

Contoh berikutnya adalah transaksi kafälah bil ujrah (pertanggungan dengan upah) dengan menyandarkan kepada pendapat sebagian kecil ulama yang berbeda dengan jumhur ulama yang melarangnya. Berdasarkan hal itulah bahwa Letter of Credit (L/C) yang mana penjamin menerima upah dibolehkan dalam fatwa DSN MUI Tahun 2009. Hukum "boleh" ini didasarkan pada karakteristik muamalah $\mathrm{L} / \mathrm{C}$ tersebut yang berkisar pada akad wakālah, hawālah dan ḍamān (kafālah). Wakālah dengan imbalan (fee) tidak haram; demikian juga tidak haram hawālah dengan imbalan. Adapun d̦amān (kafālah) dengan imbalan disandarkan pada imbalan atas jasa jāh (dignity, kewibawaan) yang menurut mazhab Syafi'i, hukumnya boleh walaupun menurut beberapa ulama mengharamkan dan ada pula yang menetapkan makruh hukumnya. Fatwa DSN-MUI menyandarkan pendapat ulama Syafi'iyah yang membolehkan ḍamān (kafālah) dengan imbalan pada ju'ālah. Dalam khazanah fikih klasik, pengenaan imbalan atas akad kafálah (kafalah bi al-ujrah) hanya dibolehkan oleh Imam Ishaq bin Rahawaih; sedangkan mayoritas ulama fikih tidak membolehkannya. Akan tetapi, setelah dilakukan telaah ulang (i'àdah al-nazar) atas 'illah hukum kedua pendapat yang saling bertentangan tersebut, serta mempertimbangkan kemashlahatan yang diperlukan oleh masyarakat pada saat ini, pendapat Imam Ishaq bin Rahawaih yang membolehkan kafălah 
bi al-ujrah itu dapat diangkat menjadi pendapat (qaul) yang dapat dijadikan pegangan (mu'tamad, räjih). ${ }^{20}$ Dengan demikian, maka salah satu masalah dalam ekonomi syariah modern dapat terjawab.

\section{d. Tahqiq al-manàt}

Metode berikutnya adalah tahqiq al-manăt (analisis penentuan alasan hukum/'illat), yakni analisis untuk mengetahui adanya alasan hukum ('illah) lain dalam satu kasus, selain 'illah yang diketahui sebelumnya, baik melalui nas, ijmà, ataupun istinbăt. Dalam kaitan ini, KH Ma'ruf Amin mengatakan bahwa tidak diberikannya bagian zakat oleh Umar bin Khattab kepada kelompok Muallafatu Qulūbuhum dan tidak dilaksanakaannya hukuman potong tangan atas pencuri pada masa paceklik atau kelaparan adalah contoh-contoh hasil penerapan tahqiq al-manät. $\mathrm{KH}$. Ma'ruf Amin mengakui bahwa metode tahqīq al-manāt telah banyak dikenal oleh para ulama terdahulu; karena itu, ajakannya adalah untuk merevitalisasikannya sehingga hukum Islam menjadi lebih dinamis. ${ }^{21}$

Contoh penerapannya adalah Fatwa DSN-MUI No. 77/DSNMUI/V/2010 tentang Murabahah Emas. Fungsi emas dalam sejarah Islam adalah sebagai alat tukar/uang. Oleh karena itu, jika emas akan diperjualbelikan maka harus dilakukan secara tunai

${ }^{20}$ Ibid., h. 34-35.

21 Amin, Fatwa dalam Sistem Hukum Islam, h. 254. untuk menghindarkan terjadinya riba nasa' (riba karena pertukaran barang ribawi sejenis yang dilakukan tidak secara tunai). Dalam Fatwa DSN-MUI No. 77/DSN-MUI/V/2010 tentang Jual Beli Emas Secara Tidak Tunai, dibolehkan emas dijadikan objek jual beli tidak tunai, baik secara angsuran (taqsit) maupun tangguh (ta'jii) selama emas tidak menjadi alat tukar yang resmi (uang). Keputusan ini antara lain didasarkan atas alasan bahwa saat ini masyarakat dunia tidak lagi menjadikan emas sebagai alat tukar (uang), tetapi memperlakukannya sebagai barang (sil'ah), oleh karena itu larangan menjual belikan emas secara tidak tunai berdasarkan hadis Nabi tidak berlaku lagi karena 'illah hukum larangan telah berubah.

Semua hal yang disebutkan di at as dilakukan karena ada kaidah bahwa hukum asal dalam ekonomi syariah adalah boleh, kecuali terdapat dalil yang mengharamkannya

$$
\text { الْأَصْلُ في الَْأَشْيَاء الْإِبَاحَةُ حَتَّى يَدُلَّ الدَّلِيلُ عَلَى }
$$

Sehingga membuka lebar pintu untuk melakukan terobosan dan inovasiinovasi dalam perumusan hukum Islam terkait ekonomi syariah.

\section{Kesimpulan}

Dari segi isinya, fatwa-fatwa DSN-MUI telah memberikan peluang

22 al-Suyuti, al-Asybah wa al-Naza'ir, h. 60 
besar bagi berkembangnya ekonomi Syariah di Indonesia. Dengan empat metode yang telah diuraikan di atas, yaitu: al-taysir al-manhaji, tafriq alhalal 'an al-ḥaram, $i$ 'àdah al-nazar, dan tahqiqq al-manāt disertai dengan pertimbangan sejumlah prinsip dalam bermuamalah dalam Islam seperti asal hukum semua muamalat itu adalah boleh kecuali ada nas yang mengharamkannya maka DSN-MUI memberikan jawaban atas pertanyaanpertanyaan yang diajukan oleh Lembaga Keuangan Syariah dalam bentuk fatwa.

Hasil dari diterbitkannya fatwafatwa DSN-MUI ini, telah membuat jalan lebar bagi para pelaku ekonomi syariah Indonesia untuk mengembangkan usaha mereka berpartisipasi dalam peningkatan kesejahteraan dan keadilan ekonomi masyarakat Indonesia, sambil memberikan ketenangan batin karena rambu-rambu syariah yang telah dipasangnya dengan jelas. 


\section{DAFTAR PUSTAKA}

al-Jauziyyah, Muhammad Ibnu Qayyim. I'lam al-Muwaqqi'in 'an Rabb al-'Alamin. Beirut:

Dar al-Jail, t.t.

al-Nadawi, 'Ali Ahmad. Mausu'ah alQawa'id wa al-Dawabit alFiqhiyyah fi al-Fiqh al-Islami, Jilid I. Riyad: Markaz al-Buhus Dar al-Ta'sil, 1999.

al-Nazwi, 'Ali Ahmad. al-Qawa'id alFiqhiyyah. Damsyiq: Dar al Qalam, 2000.

al-Suyuti, 'Abdurrahman bin Abi Bakr Jalaluddin. al-Asybah wa alNaza'ir: Dar al-Kutub alAmaliah 1990/1411.

Amin, Ma'ruf. Era Baru Ekonomi Islam Indoneia: Dari FIkih ke Praktek Ekonomi Islam. Jakarta: Elsas, 2011.

Amin, Ma'ruf. Fatwa dalam Sistem Hukum Islam. Jakarta: Elsas, 2008.

Amin, Ma'ruf. "Solusi Hukum Islam (Makharij Fiqhiyyah) Sebagai Pendorong Arus Baru Ekonomi Syariah di Indonesia (Kontribusi Fatwa DSN-MUI dalam Peraturan Perundangundangan RI)." In Orasi Ilmiah Pengukuhan Guru Besar Bidang Ilmu Ekonomi Muamalat Syariah. Malang: UIN Maulana Malik Ibrahim, 24 Mei 2017. an-Nabhan, M. Faruq. Sistem Ekonomi Islam: Pilihan Setelah Kegagalan Sistem Kapitalis dan
Sosialis. Yogyakarta: UII Press, 2000.

Hallaq, Wael B. Ancaman Paradigma Negara-Negara (Islam, Politik, dan Problem Moral Modern). Translated by Akh. Minhaji2013.

Handayani, Disfa Lidian. "Hukum Ekonomi Syari'ah: Tantangan dan Peluang dalam Pengembangan Inovasi Instrumen Keuangan Syariah." Al-Manahij: Jurnal Kajian Hukum Islam Vol. 9. No. 2 (Desember 2015).

Rozalinda. Fikih Ekonomi Syariah Prinsip dan Implementasinya pada Sektor Keuangan Syariah. Jakarta: Rajawali Press, 2016.

Taimiyah, Ibn. "Al-Fatawa al-Kubra li Ibn Taimiyah." Dar al-Kutub alAlamiyah, 1987/1408. 